\title{
Food in a colonial setting: the flora assemblage of a short-lived Seleucid-founded site in the Near East
}

\author{
Andrea Orendi ${ }^{1} \cdot$ Achim Lichtenberger $^{2}$ (1) $\cdot{\text { Oren } \mathrm{Tal}^{3}}^{3}$
}

Received: 17 July 2020 / Accepted: 4 December 2020 / Published online: 31 January 2021

(c) The Author(s) 2021

\begin{abstract}
In this paper we present the analysis of archaeobotanical material retrieved by means of flotation from well-secured features during recent excavation work carried out in 2019 and 2020 by the German-Israeli Tell Iztabba Excavation Project in the Seleucid-founded town of Nysa-Scythopolis. Founded under Antiochus IV Epiphanes (175-164 вCE) and destroyed by the Hasmonaeans in the later years of John Hyrcanus (in 108/07 BCE), the site offers a unique opportunity for observing the dietary habits of its settlers. The large sample size, namely the largest well-secured Seleucid assemblage ever analyzed in the southern Levant, together with its versatile provenance exhibit previously unknown information for the Hellenistic southern Levant vis-à-vis a unique case-study of high resolution systematic archaeobotanical analysis. The botanical assemblage from Tell Izțabba gives a clearer picture of botanical dietary practices in Hellenistic Palestine. By presenting the archaeobotanical data of the published Hellenistic assemblages from the southern Levant, we offer a comprehensive overview of the agrarian resources cultivated and consumed as food at the time and period.
\end{abstract}

Keywords Hellenistic $\cdot$ Southern Levant $\cdot$ Tell Iẓțabba $\cdot$ Cereals $\cdot$ Legumes $\cdot$ Fruit

\section{Introduction}

The study of organic remains as a means of reconstructing ancient diet in the Hellenistic southern Levant is patchy. Traditionally, classical archaeology has favoured the study of monumental physical remains such as architecture, sculpture, or iconographic sources (Hölscher 2006), and data from natural sciences are neglected. Yet, the analysis of organic remains from archaeological sites provides a unique insight into the dietary preferences of their inhabitants. Thus, for example, when it comes to the study of animal bones, the

Communicated by S. M. Valamoti.

Achim Lichtenberger

lichtenb@uni-muenster.de

1 ArchaeoConnect GmbH, Department of Archaeological Sciences, Archaeobotany Laboratory, August-Bebel-Straße 16, 72072 Tübingen, Germany

2 Institut für Klassische Archäologie und Christliche Archäologie/Archäologisches Museum, Westfälische Wilhelms-Universität Münster, Domplatz 20-22, 48143 Münster, Germany

3 Department of Archaeology and Ancient Near Eastern Cultures, Tel Aviv University, 6997801 Tel Aviv, Israel relatively few reports from secure contexts in the Hellenistic southern Levant suggest that sheep and goats were widely preferred for consumption, supplemented with cattle, chicken, pigs and fish, with other species quite underrepresented (Perry Gal 2019; Pines et al. 2020). While the faunal remains in the Levant have received some attention, our knowledge on the consumption of cereals, pulses, fruits and vegetables is far less conclusive, given the fact that botanical remains have hardly been studied in Levantine settlements such as cities, towns and villages. Here we will try to fill this gap by analysing the diet of Tell Iztabba (East) - a 2nd century вCE Seleucid-founded town known in the historical sources as Nysa-Scythopolis.

The data from Seleucid Tell Izțabba permits a wider view of the botanical component of the diet of Hellenistic Palestine, being one of a few Seleucid-founded sites in the southern Levant. A broad-based analysis of various archaeobotanical assemblages from a single period involves many challenges. Methodological problems in comparing archaeobotanical data from different sites arise due to variations in sample strategy, sample number, and plant density, just to mention a few. Moreover, the presentation of presence-only data and the difference in the site structure often hampers a comprehensive multi-site analysis (Colledge et al. 2004; 
Riehl 2009). Nevertheless, comparative multi-site studies provide significant results when it comes to developments and/or changes in agrarian resources in a wide area of research over a long period of time (e.g. Dennell 1992; McCorriston and Weisberg 2002; Colledge et al. 2004; Conolly et al. 2008; Riehl 2009; Stika and Heiss 2013; Effenberger 2018; Kreuz and Marinova 2017; Orendi 2018). For the scope of this paper, the Hellenistic period offers a good opportunity to conduct a multi-site analysis. First, the Hellenistic period of the southern Levant is quite short, lasting less than 300 years from the inauguration of Alexander the Great in 336 BCE to the termination of Seleucid rule by Pompeius in 63 все. Second, the archaeobotanical material from the southern Levant dating to Hellenistic times is manageable. Including the archaeobotanical data from Tell Iztabba, only 13 sites in the wider area of the southern Levant provide plant material from the Hellenistic period (Fig. 1). Our comprehensive consideration of published and original, new archaeobotanical evidence from the southern Levant during the Hellenistic period provides for the first time an overview of agricultural practices and plant resources used as food or for other purposes in the region.

\section{Geographical setting}

Tell Iztabba is located in the north of Israel within the Beth She' an National Park. It is situated on the edge of the Jordan Valley, which was also an important transport link from the East Jordanian mountains to the Mediterranean coast (Fig. 1).

The Jordan Rift Valley is part of the East African-Syrian Rift Valley and cuts deep into the landscape, dividing the southern Levant into the Cis- and Transjordan spheres. In the region of Beth She' an the Jordan Valley opens onto a fertile plain and continues as an extension of the Jezreel Valley. The Beth She'an Valley is traversed by the Harod River which is fed by a strong spring west of the modern town of Beth She'an. Other tributaries which flow into the Jordan River from the west only carry water in the winter months. These small tributaries, nevertheless, left marshes and swamps, which were already drained in ancient times for the cultivation of arable land (Orni and Efrat 1966, pp. 91-92).

The climate in the region of Beth She'an is bi-seasonal, characterized by hot, dry summers and wet, moderate winter months with most rainfall during December, January and February. The present-day annual temperature average is about $20{ }^{\circ} \mathrm{C}$, August being the hottest month with $30^{\circ} \mathrm{C}$ on average and January the coldest with $13{ }^{\circ} \mathrm{C}$ on average (Singer 2007, p. 163). The present-day mean annual precipitation is about $340 \mathrm{~mm}$, which is classed as semi-arid climate and is therefore within the $250 \mathrm{~mm}$-isohyet for rain-fed agriculture (Zohary 1962, p. 21). However, crops

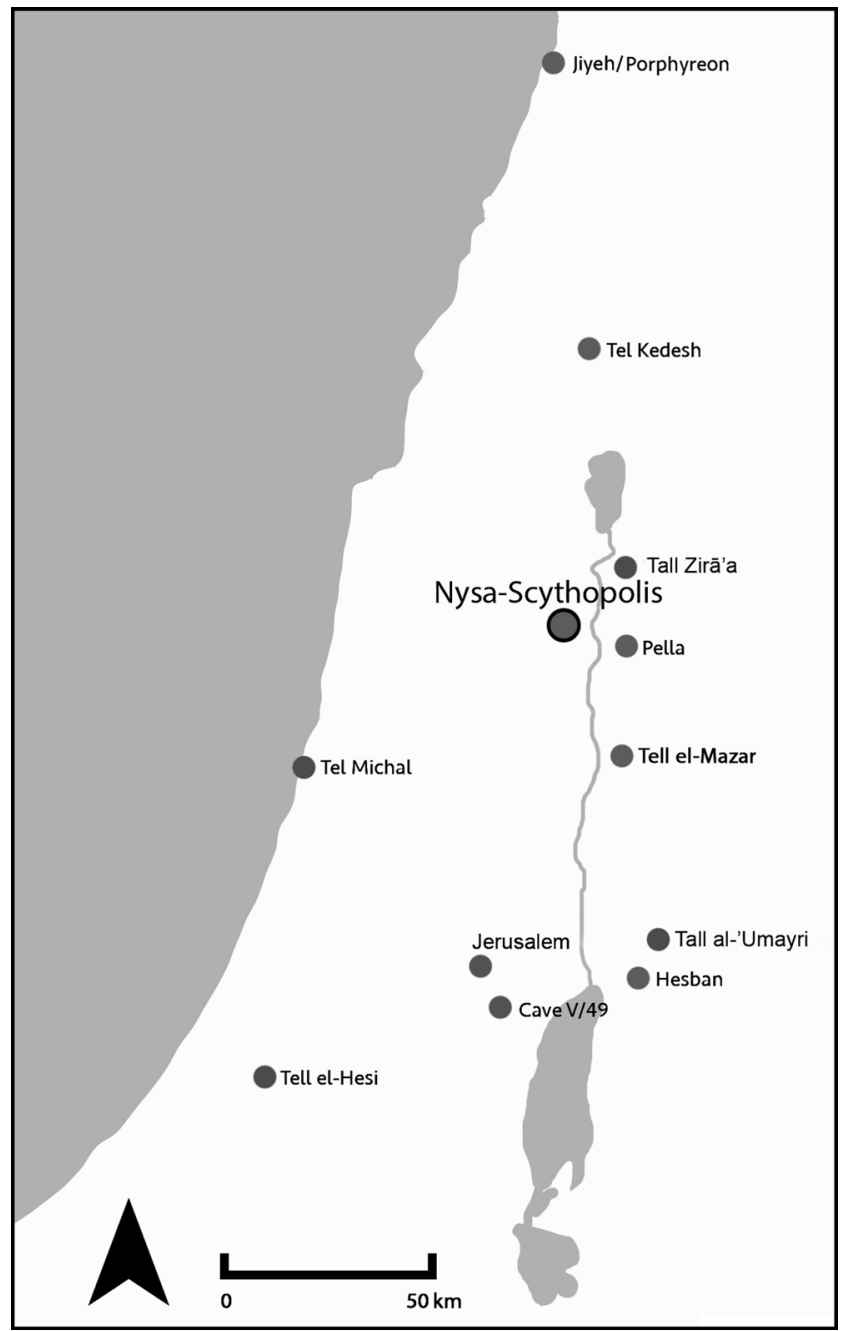

Fig. 1 Map of the southern Levant with the location of Tell Iztabba (Nysa-Scythopolis) and the other Hellenistic sites with archaeobotanical data mentioned in the text

with high water requirements like flax, grape or pea need a greater water supply (Riehl 2009). In addition, due to successive years of drought and high inter-annual fluctuations in precipitation, a constant water supply is vital for a stable agriculture. This was achieved with the help of irrigation water e.g. from the Harod River (Singer 2007, p. 163). Studies on palaeo-climate proxies show some significant variation in arboreal pollen, especially at Birkat Ram in the northern Golan Heights. The decline of arboreal pollen and the rise of pastureland indicators, however, is rather a result of increased settlement activities during the Hellenistic period (Neumann et al. 2007). Similar data and conclusions were obtained from several pollen cores in the Dead Sea area as well (Neumann et al. 2010).

The Lisan-marl of the Jordan Valley was formed when the valley was covered by the Lisan Lake. The layers of Lisanmarl created the Lisan-marl soils, which extend throughout 
the whole central and southern Jordan Valley. The soils are white-grey in colour and contain a high proportion of lime. They are inherently saline. However, in the northern part of the Jordan Valley the salts have been washed out over time resulting in a fertile substrate (Zohary 1962, p. 15). Gradually the Jordan River formed terraces of which the lower is covered with alluvial sediments caused by flooding events. The modern town of Beth She' an and its historic sites are situated on an upper terrace with an elevation of $-160 \mathrm{~m}$ a.s.l. on which alluvial soils also occur along the smaller water streams of the Beth She' an Valley (Orni and Efrat 1966, pp. 91-92). The natural conditions presented support the herbaceous and dwarf shrub vegetation of the IranoTuranian plant-geographical territory. In the Beth She'an Valley brushwood plants of the Zizyphion loti alliance are common (Zohary 1962, Map 5), with Ziziphus lotus being the dominant species (Zohary 1962, pp. 132-133). However, the extensive agricultural and settlement activities since ancient times left their mark on the natural vegetation of the Beth She'an Valley (Zohary1962, pp. 15, 51, Map 4), displacing native plants and replacing them in cultivated land with segetal and ruderal plants of a special Prosopis farcta alliance. The primary habitat of $P$. farcta is along the Jordan River and its tributaries (Zohry 1962, pp. 15, 167), but in the cultivated areas of the Lisan-marl soils $P$. farcta became a weed in the cultivated fields (Zohary 1962, p. 220).

\section{Historical setting}

In Graeco-Roman times Tell Izțabba was part of the settlements of classical-period Beth She'an (Nysa-Scythopolis; on the history cf. in the following Ebeling et al. 2020, 2021). The elongated hill of Tell Izțabba was located north of the acropolis formed on top of biblical Tel Beth She'an (Tell el-Huṣn), separated from it by the Harod River. While biblical Tel Beth She'an shows almost continuous occupation in its settlement history from prehistoric to Islamic times, according to our knowledge Tell Izțabba was inhabited only in the Early Bronze Age, the Hellenistic period and less intensively in the Roman and Byzantine periods.

Our research focuses on the Hellenistic period, as the site of Tell Iztabba provides us with a unique situation in chronological terms. The Hellenistic period settlement was founded in the first half of the 2nd century BCE, probably under Antiochus IV Epiphanes (175-164 BCE) and was destroyed towards the end of that century by the Hasmonaeans, under John Hyrcanus (in 108/07 BCE). The Seleucids implemented large-scale urbanization programs in the region given its relative proximity to the Ptolemaic Kingdom (Thiel 2007; Tal 2011). These settlements, from which some of the Decapolis centres evolved in Roman times and were settled by veterans of the Seleucid army, integrated the local populations of Phoenicians, Jews, Samaritans and Edomites.
A reaction to the urbanization program of Antiochus IV was the Maccabean uprising in Judea, which resulted in the formation of an independent Jewish state in the region. This state expanded, conquered and destroyed some of the Hellenistic-founded settlements under different Hasmonean rulers and kings. Following the site destruction in 108/07 BCE of Tell Iztabba by John Hyrcanus it was never resettled by the Hasmoneans. This means that the archaeological findings of the Hellenistic period on the site have a narrow chronological framework, as the foundation and destruction horizons are firmly dated by both the historical sources and the archaeological findings. Accordingly, it is possible to examine firmly dated evidence and to obtain information on the material culture of the site settlers.

\section{Archaeology}

Excavations at Tell Iztabba were initially carried out in the second half of the 20th century and followed up by the work of the German-Israeli Tell Izțabba Excavation Project. Our Project at the site, funded by the German-Israeli Foundation, was launched in 2019. It focuses on several aspects, including (1) the precise date of the Hellenistic (i.e. Seleucid) foundation, (2) the process of the site's crystallization as part of a Roman Decapolis, (3) similarities and differences between other such Hellenistic foundations in Palestine and the Levant, and (4) the diet of the inhabitants of the Seleucid-founded site through the analysis of animal bones, botanical remains, and residues recovered from small and large pottery containers.

Initially, magnetic prospection was carried out on the accessible areas of Tell Iztabba (Lichtenberger et al. 2020). It was found that although the town is generally regular in layout, the settlement is still oriented towards the natural topography. In September 2019 and February 2020 excavations were undertaken in four selected areas. In Area A, on the northern edge of the settlement, Byzantine and Early Bronze Age features were discovered, while in Areas B, C and $\mathrm{D}$ on the central eastern parts of the Tell, mainly Hellenistic house structures were unearthed. In Area D a Byzantine building was also discovered. Early Bronze Age features were encountered in many places in the lowest layers (especially in Areas C and D).

The site's Hellenistic layers lie directly on top of Early Bronze Age remains with no significant post-Hellenistic and pre-Byzantine structures unearthed to date. The various excavations of the Hellenistic layers of Tell Iztabba have yielded a large well-planned Hellenistic settlement with domestic structures, especially in Areas B and C. The houses in the residential areas are of the central courtyard house type, with rooms of different sizes arranged around a courtyard, as is typical of other sites in the Hellenistic Levant (cf. Ebeling et al. 2020, 2021; for the southern Levant, see Tal 
2017, pp. 97-115). These houses were finally destroyed in 108/107 BCE. In the destruction layers, inventories of houses were found with rich ceramics, metal utensils, and coins. The material culture of the town is closely connected to the larger eastern Mediterranean cultural zone and the Seleucid settlers were integrated in the Hellenistic koiné.

Until now, no studies on the dietary habits of the inhabitants of Tell Iztabba have been undertaken and this will be the focus of the following sections. It is the aim of this paper to contribute to a better understanding of the plant diet and living conditions of the site's inhabitants, be it veterans of the Seleucid army or the integrated local populations. Moreover, the samples were analysed and compared with other contemporary sites from the southern Levant to develop a comprehensive overview of the agrarian resources cultivated and consumed as food at the time and period.

\section{Materials and methods}

\section{Data recovery from Tell Izțabba}

During the 2019 and 2020 seasons, a total of 44 samples for archaeobotanical analyses (ESM 1) with an overall volume of about 1,164 1 were taken by the archaeological team. The intention was to obtain representative samples from the settlement. The plant remains come from well-secured and well-dated contexts. Usually, single samples were taken from fills close to floors that represent occupational layers of domestic structures found in Areas B (L209, L218, L242, L253, L262; ESM 2 Fig. 1), C (L309, L314; ESM 2 Fig. 2) and D (L413, L426, L433, L435, L438; ESM 2 Fig. 3). However, it was decided not to sample every room, rather only selected areas where clean and undisturbed close-to-floor levels were reached. In a few cases, these levels are made up of destruction layers (Area C, L309/L314). More material stems from other loci within the Hellenistic settlement like the fill of a sewage channel in one of the Hellenistic houses of Area B (L221). The volume of the samples mentioned is restricted to one or two buckets of soil per sample. One bucket weighs $12 \mathrm{~kg}$, which is approximately the equivalent of 6.51 of sediment. When more than one bucket was taken for a single sample the total weight and volume was calculated accordingly (Table 1; ESM 1). In others, contents of silos were sampled at a far higher resolution. For example, ten soil samples were taken in large quantities from Silo 335 (L338) owing to its considerable capacity (totalling some $1,668 \mathrm{~kg} \approx 904 \mathrm{l}$ ) and floated to collect plant material. In Silo 335 (L338) we sampled only one bucket from the upper archaeological layer in 2019. When it turned out that these samples were rich in archaeobotanical material, it was decided to continue the excavation in 2020 and to sample the entire sediment volume. Therefore, the intensity of sampling of this evidence is far higher than from other layers. Due to security reasons, the excavation had to be stopped at a depth of $3.5 \mathrm{~m}$ and therefore the bottom of the silo was not reached. The five soil samples from silo 343 (L344) were fewer in number due to its smaller capacity (totalling some $120 \mathrm{~kg} \approx 65 \mathrm{l}$ ). The two storage tanks (silos; Area $\mathrm{C}$ ) were excavated in one of the houses. These silos were circular stone-built shafts with an opening whose diameter varies from $0.45 \mathrm{~m}$ (L344) to $0.6 \mathrm{~m}$ (L338), while the shafts widen as they become deeper, reaching up to $3.5 \mathrm{~m}$ (ESM 2, Fig. 2). The inner walls of the silos were designed with niches used as steps that would facilitate their maintenance. During the excavation, the silos were found filled with earth. The little pottery that was found in the silos dates the structures to the late 2 nd century BCE.

The samples were hand-floated in the dig-house using buckets for soaking the sediment for about $24-48 \mathrm{~h}$ in general. The botanical remains were then decanted into a sieve with a mesh-size of $1 \mathrm{~mm}$ in which the seeds were also kept for drying. Therefore, the retrieval method potentially biases the archaeobotanical data towards large plant finds as we may have missed collection of small plant finds like chaff remains and seeds of wild species. The heavy residue was discarded without prior scanning for botanical remains. As a result, heavy plant remains that did not float might have been missed and were not retrieved. The light fractions were then sent to the Archaeobotany Laboratory of ArchaeoConnect in Tübingen for further examination. Although the plant remains were recovered with a sieve of $1 \mathrm{~mm}$ size during bucket flotation, it was decided to divide the dried light fraction to four fractions $(2,1,0.5$ and $0.2 \mathrm{~mm})$ including mesh sizes smaller than $1 \mathrm{~mm}$ to facilitate the sorting process. The reasons for this were the fact that sometimes wet macro botanical remains as well as sediment grains (like sand) smaller than $1 \mathrm{~mm}$ stick on the bigger residues and, when dried, the residues fall apart again. Sorting of the macro remains was done with the help of a binocular stereomicroscope (Zeiss Stemi 305 ) with $8 \times$ to $40 \times$ magnification. The charcoal fragments were not extracted from the light fraction.

Identification of the charred seeds was done using the seed reference collection of the Archaeobotanical Laboratory at the University of Tübingen and identification literature such as Nesbitt (2006), Jacomet (2006), Cappers et al. (2012) and Neef et al. (2012). Each complete seed was counted as one. If at least half a seed was preserved, it was also counted as one, except for cereals of which two halves or four quarters of fragmented cereals were added up to make one seed. Some samples contained a single olivestone fragment, which in turn was counted as one olive stone. These samples are marked with an asterisk in ESM 1. The $0.5 \mathrm{~mm}$-fraction of one sample (BP 42, ESM 1) was split into two halves with the help of a riffle box. One half 

finds from Tell Izțabba; 1 Grain of free-threshing wheat (Triticum durum/aestivum; dorsal, ventral, and lateral view); 2 Seed of a lentil (Lens culinaris); 3 Grain of woolly brome (Bromus lanceolatus; dorsal and ventral view); 4 Grain of darnel grass type (Lolium temulentumtype; dorsal and ventral view); 5 Grain of annual rye-grass (Lolium rigidum; dorsal and ventral view); 6 Grain of Mediterranean needle grass (Stipa capensis; lateral view); 7 Noncarbonized achene of crown daisy (Glebionis coronarium); 8 Non-carbonized mericarp of small-flowered mallow (Malva parviflora). Scale bars $=1 \mathrm{~mm}$
Fig. 2 Images of selected plant
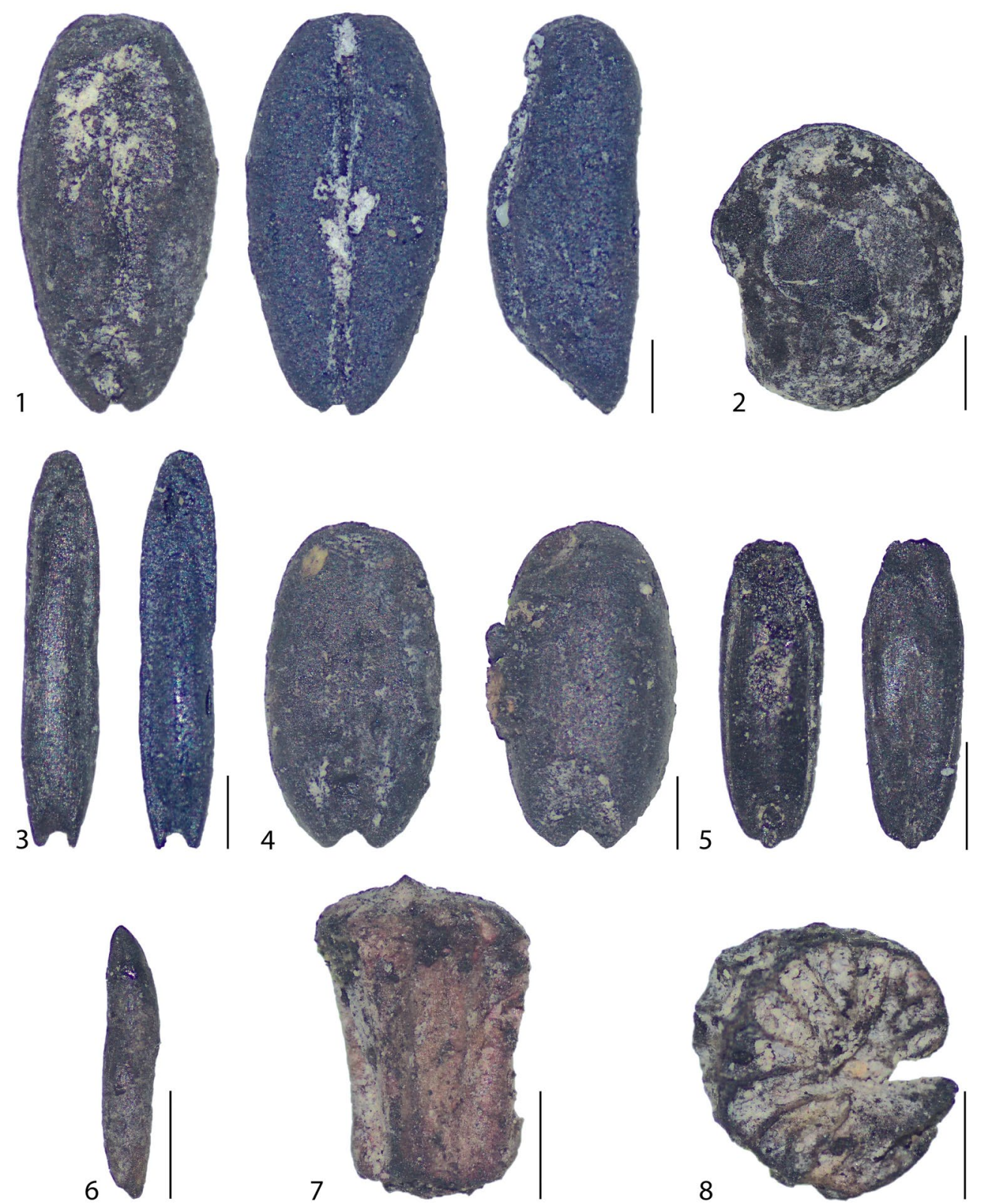

was sorted for botanical remains, and the number of plant finds from this fraction was summed up accordingly. The calculated counts are marked with a \# in ESM 1.

For Table 1 single taxa were sometimes allocated to groups of taxa to simplify the data list. The spikelet forks and glume bases of the hulled wheat (Triticum dicoccum/monococcum) were amalgamated as chaff. Especially for the wild species category many taxa were grouped to family level (Brassicaceae, Fabaceae, Poaceae) and taxa present in very low amounts were subsumed under the category of other wild species. For the interpretation of the archaeobotanical material, the absolute number of seeds, and the percentage of the absolute number of seeds are listed separated by loci. In addition, the percent ubiquity of the identified seeds from the floor loci and the bigger silo (L338) was calculated. The percent ubiquity was not calculated for the finds from the sewage channel and the smaller silo (L344) due to the small number of samples taken from these installations.

\section{Archaeobotanical data from the Hellenistic southern Levant}

The archaeobotanical data from Hellenistic sites comes from published archaeobotanical papers or reports included in the final publications of single sites (see Table 2). The research area covers the core area of the southern Levant extending 

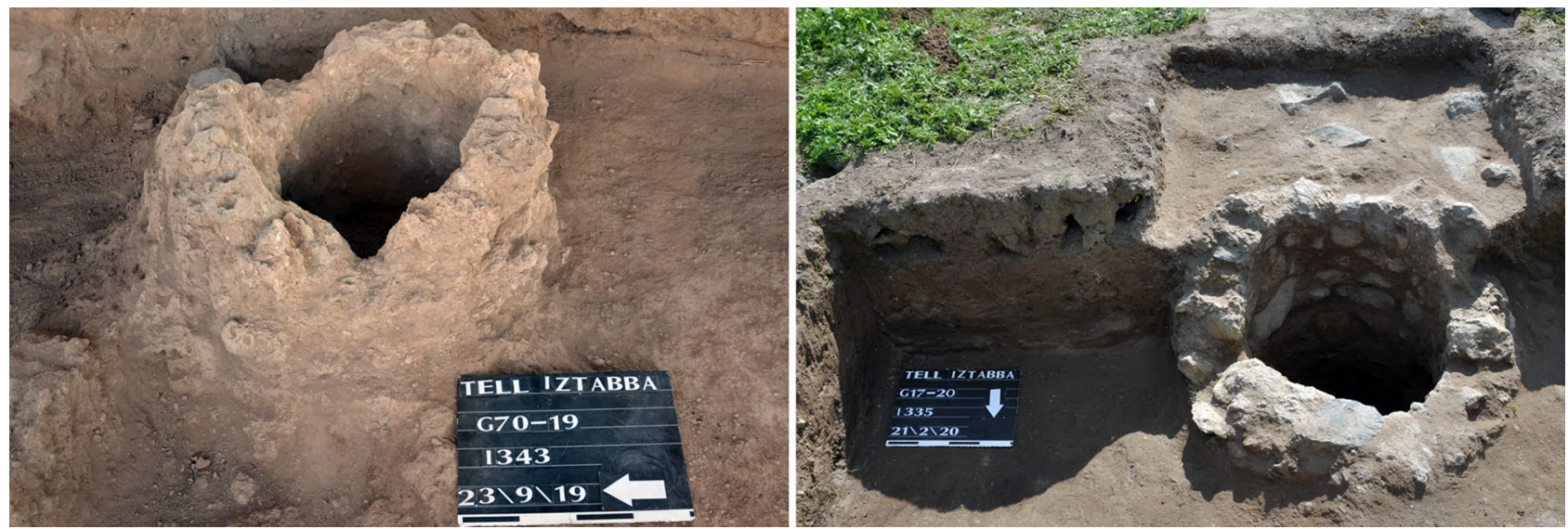

Fig. 3 The two silos: Silo 1 on the left, Silo 2 on the right

north to Lebanon (Fig. 1). The spatial distribution of the 13 mainly civic and/or military settlements under investigation covers all physio-geographical units of the southern Levant. There is a concentration of settlements along the central Jordan Valley (Tell Izțabba, Pella: Willcox 1992; Tell el-Mazar: Yassine and van der Steen 2012), with Tel Kedesh controlling the Hulah valley (Berlin et al. 2003; Borojevic 2011). Three sites are located on the Transjordan Plateau of which Tall al-'Umayri (Ramsay and Mueller 2016) and Hesban (Gilliland 1986) are situated close together on the Madaba Plains south of Amman. Tall Zirā'a (Olsvig-Whitaker 2017) is located on the wide bed of Wadi al- 'Araba which opens to the Jordan Valley between the Beth She' an Valley and Lake Kinneret. The other sites are distributed throughout the southern Levant: Jerusalem (City of David—Liphschitz and Waisel 1992; Giv'ati Parking Lot-Frumin and Tchekhanovets 2016); the Shephela (Tell el-Hesi-Stewart 1978), the central coastal plain (Tel Michal-Liphschitz and Waisel 1989); the Judean desert (Cave V/49-Melamed 2002); and the Lebanese coast between Saida and Beirut (Jiyeh/Porphyreon-Badura et al. 2016). The data from the different sites are listed in Table 2 to get a quick overview of the Hellenistic plant material. Besides the archaeobotanical data, relevant information like site structure, recovery technique and sampling strategy were added. Wherever possible the counts and the percent proportions of the taxa are listed.

As the archaeobotanical assemblages of the southern Levantine Hellenistic sites differ in sampling and data quality, it was decided to separate the archaeobotanical data of the Hellenistic sites into four groups (Table 2). Group 1 includes the sites in which systematic or judgmental sampling and (bucket-) flotation were conducted. Moreover, the data are presented by the total number of finds and the calculated find density per sample is above 10. It was not possible to consider the find density per litre as a value for comparison because many of the publications gave no indication of the sediment volume. Therefore, the find density per sample was the value taken for comparison. Together with Tell Iztabba the first group comprises Tel Kedesh (Berlin et al. 2003; Borojevic 2011), Pella (Willcox 1992), Tell el-Mazar II (Yassine and van der Steen 2012) and Hesban (Gilliland 1986). The samples come from various contexts such as floors (Tell Iztabba), occupation layers (Tell Izțabba, Tel Kedesh), silos (Tell Izțabba), and a sewage channel (Tell Iztabba). However, it is not always clear what kind of contexts were sampled. The high number of botanical finds at Tell el-Mazar II probably derive from a storage context. Although this information is not mentioned in the publication, it is obvious that the masses of botanical finds come from a single sample taken from a destruction layer (Stratum I, Area GH 8/8-Yassine and van der Steen 2012) which contains masses of carbonized linseeds and Cuscuta seeds. The other botanical finds from Tell el-Mazar II were distributed among the other 10 samples.

The archaeobotanical assemblages of Group 2 differ from Group 1 mainly in their low find density per sample, although the sampling strategy and recovery technique in both groups are the same. Jiyeh/Porphyreon in Lebanon (Badura et al. 2016), and Tall al-'Umayri in Jordan (Ramsay and Mueller 2016) fulfil the criteria for inclusion within this group: At Jiyeh/Porphyreon samples were mainly taken from the occupation layers of different rooms and streets, whereas at Tall al-'Umayri the samples came from a tabun, several pithoi and different fills.

Group 3 comprises the data assemblages, which are published as presence-only data. Some of the Hellenistic plant finds are presented as single carpological finds retrieved from anthracological data analysis (Tel Michal—Liphschitz and Waisel 1989; City of David-Liphschitz and Waisel 1992). The plant remains from Tell el-Hesi (Stewart 1978) and Tall Zirā'a (Olsvig-Whitaker 2017) come from different fillings and installations such as ovens, pits or floors but are 
Table 1 The archaeobotanical data from Tell Izțabba of selected loci. $N$ number of finds; \% percent proportion of taxa; $U$ percent ubiquity of taxa. $u c$ uncharred; $c$ charred; $m$ mineralized

\begin{tabular}{|c|c|c|c|c|c|c|c|c|c|c|}
\hline Context & Floors & & & $\begin{array}{l}\text { Sewa } \\
\text { L221 }\end{array}$ & channel & Silo & & Silo L & & \\
\hline No of samples/volume (1) & $16 / 10$ & & & $1 / 13$ & & $5 / 65$ & & $10 / 90$ & & \\
\hline Find density/l & 2.9 & & & 0,8 & & 0.6 & & 1.4 & & \\
\hline No of taxa/seeds of modern remains & $4 / 6$ & & & $*_{-}$ & & $4 / 12$ & & $11 / 36$ & & \\
\hline No of taxa/seeds of crop species & $16 / 77$ & & & $4 / 6$ & & $8 / 23$ & & $27 / 55$ & & \\
\hline No of taxa/seeds of wild species & $32 / 20$ & & & $3 / 5$ & & $10 / 1$ & & $27 / 30$ & & \\
\hline & $\mathrm{N}$ & $\%$ & $\mathrm{U}$ & $\mathrm{N}$ & $\%$ & $\mathrm{~N}$ & $\%$ & $\mathrm{~N}$ & $\%$ & $\mathrm{U}$ \\
\hline Modern seeds & & & & & & & & & & \\
\hline Centaurea sp., achene, uc & & & & & & & & 13 & 1 & 30 \\
\hline Glebionis coronaria, achene, uc & 1 & 0.3 & 6.25 & & & 1 & 2.5 & 187 & 14.9 & 80 \\
\hline Malva parviflora, seed, testa, uc & & & & & & & & 78 & 6.2 & 60 \\
\hline Hordeum sp., grain, chaff, uc & & & & & & 1 & 2.5 & 9 & 0.7 & 40 \\
\hline cf. Rosaceae, fruit, uc & 4 & 1.3 & 18.75 & & & 8 & 20 & 75 & 6 & 90 \\
\hline other modern seeds, uc & 4 & 1.3 & 18.75 & & & 2 & 5 & 7 & 0.6 & 30 \\
\hline Cultivated species & & & & & & & & & & \\
\hline Lens culinaris, seed, c & 6 & 2 & 25 & & & & & 33 & 2.6 & 60 \\
\hline Vicia/Lathyrus/Pisum sp., seed, c & 3 & 1 & 12.5 & & & & & 6 & 0.5 & 30 \\
\hline Vicia faba, seed, c & & & & & & & & 2 & 0.2 & 20 \\
\hline Fabaceae sativae, seed, c & 4 & 1.3 & 18.75 & & & 2 & 5 & 14 & 1.1 & 60 \\
\hline Linum usitatissimum, seed, c & & & & & & & & 2 & 0.2 & 10 \\
\hline Ficus carica, nutlet, c & 4 & 1.3 & 12.5 & & & 1 & 2.5 & 16 & 1.3 & 40 \\
\hline Olea europaea, stone, c & 6 & 2 & 37.5 & 1 & 9.1 & 1 & 2.5 & 21 & 1.7 & 70 \\
\hline Hordeum vulgare, grain, c & 5 & 1.6 & 12.5 & & & 2 & 5 & 19 & 1.5 & 60 \\
\hline Hordeum vulgare, rachis, c & & & & & & & & 3 & 0.2 & 20 \\
\hline Triticum dicoccum, grain, c & 4 & 1.3 & 12.5 & & & & & 9 & 0.7 & 50 \\
\hline T. dicoccum/monococcum, grain, c & 11 & 3.6 & 25 & & & 1 & 2.5 & 117 & 9.4 & 90 \\
\hline T. aestivum/durum, grain, c & 5 & 1.6 & 25 & 2 & 18.2 & & & 105 & 8.4 & 90 \\
\hline T. durum, rachis, c & & & & & & & & 4 & 0.3 & 30 \\
\hline Triticum sp., grain, c & 4 & 1.3 & 18.75 & 2 & 18.2 & 1 & 2.5 & 14 & 1.1 & 50 \\
\hline Cerealia, grain, c & 21 & 6.9 & 56.25 & 1 & 9.1 & 5 & 12.5 & 177 & 14.2 & 100 \\
\hline cf. Prunus dulcis, seed, c & & & & & & & & 1 & 0.1 & 10 \\
\hline Vitis vinifera, pip, c & 4 & 1.3 & 18.75 & & & & & 14 & 1.2 & 60 \\
\hline Wild species & & & & & & & & & & \\
\hline Glebionis coronaria, achene, c & 93 & 30.4 & 31.25 & & & & & 1 & 0.1 & 10 \\
\hline cf. Echium judaeum, nutlet, m & 6 & 2 & 12.5 & & & 3 & 7.5 & 2 & 0.2 & 10 \\
\hline Brassicaceae, stem, fruit, seed, c & 41 & 13.4 & 12.5 & & & 1 & 2.5 & 4 & 0.3 & 30 \\
\hline Fabaceae, seed, c & 8 & 2.6 & 18.75 & & & & & 18 & 1.4 & 80 \\
\hline Trifolium sp., seed, c & 17 & 5.6 & 25 & & & 1 & 2.5 & 51 & 4.1 & 90 \\
\hline Lolium spp., grain, c & 14 & 4.6 & 43.75 & 3 & 27.3 & 5 & 12.5 & 165 & 13.2 & 90 \\
\hline Poaceae, grain, c & 31 & 10.1 & 68.75 & 1 & 9.1 & 4 & 10 & 56 & 4.5 & 70 \\
\hline Other wild species, c & 10 & 3.3 & 18.75 & 1 & 9.1 & 1 & 2.5 & 29 & 2.3 & 50 \\
\hline Indet & 196 & & & 10 & & 34 & & 362 & & \\
\hline Ostracods & 1 & & & & & & & & & \\
\hline Sum per context & 306 & & & 11 & & 40 & & 1,254 & & \\
\hline
\end{tabular}


吾营

突离

ีㅗㅀ

过

눈

그

矛苞

作

.

응

iv

인

需实

의

워․

훈

记

产营

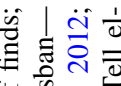

पै छै

言部

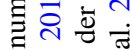

之. 히

产家㤩

ली

हैं क्षे

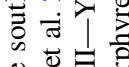

‡.

पे

造! 方

.0

造这

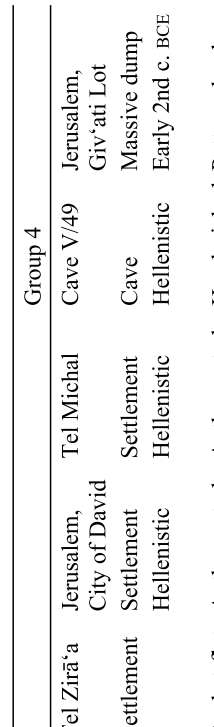

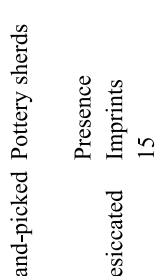

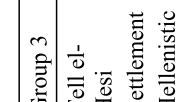

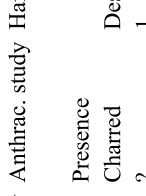

突

总营离

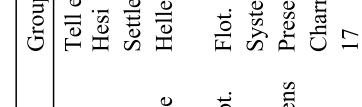

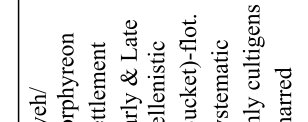

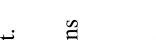

总

焉

ब्ञ

可 苂

䛶窟

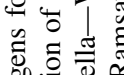

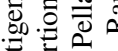

उे 웅

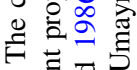

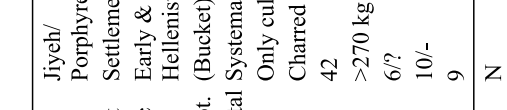

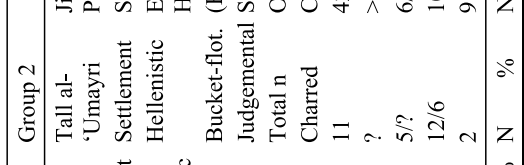

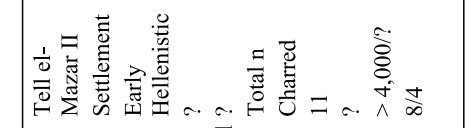

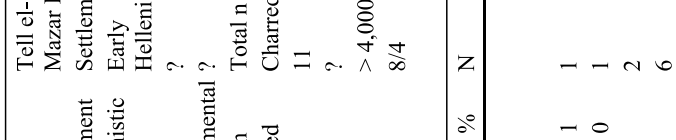

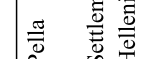

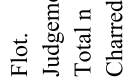

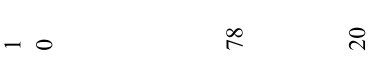

ล $\stackrel{\infty}{-}$

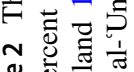

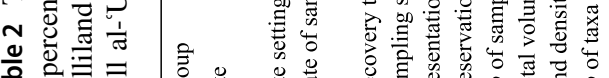

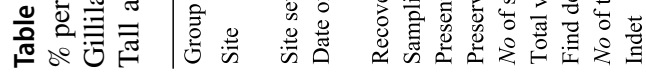

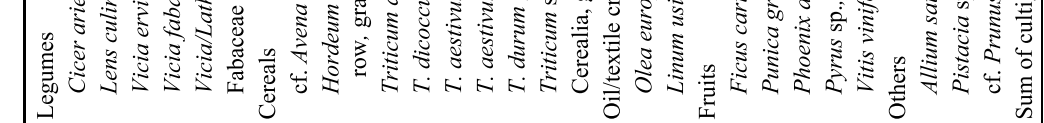


available only as presence data, although systematic sampling and flotation was conducted at both sites.

Group 4 includes the sites with different preservation status and different settings. At Cave V/49 the seeds and fruits were desiccated (Melamed 2002). In addition, the site setting is different from those of Groups 1 to 3 . The massive Hellenistic filling layers from the excavations at the Giv'ati Parking Lot in Jerusalem (City of David) revealed sherds with imprints of fig leaves (Frumin and Tchekhanovets 2016).

\section{Results}

\section{The finds from Tell Izțabba}

The 44 samples examined here from Tell Iztabba contained 2,160 identifiable seeds, giving a find density per sample of 0.3 to 23 seeds/l (ESM 1). The mineral soils as well as the semi-arid to sub-humid climate regimes of the southern Levant usually allow the preservation of plant remains in a carbonized condition. Accordingly, the archaeobotanical material from Tell Izțabba consists mainly of charred plant remains (except the mineralized nutlets of cf. Echium judaeum). The preservation of the macro remains was moderate to low. The carbonized plant finds were often fragmented, bloated and spongy, resulting in many indets $(\mathrm{N}=661)$ of organic origin that were not included into the statistical analyses of Table 1 . The plant finds are divided into cultigens ( 31 taxa) and wild species (62 taxa). The category of modern plant remains was also added in Table 1 and ESM 1, as one-third $(\mathrm{N}=406)$ of the archaeobotanical record of Tell Iztabba is made up of uncharred seeds probably of modern origin (Fig. 2). However the discussion of the archaeobotanical material from Tell Iztabba concentrates on the contexts mentioned above (two silos, one sewage channel, and various floors), which account for a large part of the macro remains with 1,611 identifiable finds (Table 1). The spatial distribution of the archaeobotanical remains from these loci depends both on the volume of sediment processed and on the locus structure. The sample from the sewage channel and the small silo (L344) provided fewer plant finds which randomly entered the locus. The bigger silo (L338) and the numerous samples from the various floor contexts contained the most plant finds.

\section{The finds from the floors}

16 samples derive from 12 different floor contexts spread throughout Areas B (ESM 2, Fig. 1), C (ESM 2, Fig. 2), and D (ESM 2, Fig. 3). Despite the high number of contexts sampled, the amount of plant finds is quite low: only 306 macro remains come from the floors of the domestic structures. Only two samples contained more than 50 plant remains, these being recovered from contexts L262 (Area B) and L426 (Area D).

Most cultigens are cereal grains of which most could not be specified even to genus level due to the poor preservation of the grains. The remains of barley (Hordeum vulgare), free-threshing wheat (Triticum durum/aestivum), and wheat (Triticum sp.) are almost evenly distributed. The hulled wheat remains (Triticum dicoccum/monococcum) are higher in number than the other cereals, but the chaff remains of hulled wheat are double in number to the finds of hulled wheat grains (Table 1). Besides these, legumes-of which lentil (Lens culinaris) is the most frequent species, fragments of olive stones (Olea europaea) and single grape pips (Vitis vinifera) were found (Table 1; Fig. 2). About three-quarter of the floor assemblages are remnants of wild plants. The crown-daisy (Glebionis coronarium) together with seeds of the Brassicaceae and grains of wild grasses make up the largest part of the wild plant species.

\section{Sewage channel (I207/L221)}

The number of macro remains from the channel is extremely small (11 macro remains). The sample contained some grains of (free-threshing) wheat and one fragment of an olive stone. Single finds of wild grasses were also part of the assemblage from the sewage channel (Table 1).

\section{Silo1 (I343/L344)}

The sediment from the smaller silo (L344; Fig. 3) provided a small number of plant finds $(\mathrm{N}=40)$. Cereals accounted for most cultigens, but many of them were not identifiable to the genus level. Some barley grains and one spikelet fork of hulled wheat were among the cereal remains (Table 1; ESM 1). The seeds of legumes also could not be assigned to a specific species. The seeds of wild species are evenly distributed among the various taxa, with a preponderance of darnel grass grains and mineralized nutlets, possibly of Judean viper's bugloss (cf. Echium judaeum).

\section{Silo 2 (I335/L338)}

About one-half of the archaeobotanical assemblage of Tell Izțabba $(\mathrm{N}=1,254)$ derives from the ten samples taken from the bigger silo (Fig. 3). Again, the find density was low. Still, the sheer volume of sediment that was processed resulted in the highest number of plant finds compared to other loci. In addition, the variety of the plant assemblage from this locus is the highest found so far in Tell Iztabba. The remains of cultivated species outnumbered those of wild species (Table 1). Many cultigens are different kinds of cereals. The wheat is represented by hulled wheat and 
free-threshing wheat. The proportion of free-threshing wheat grains and hulled wheat chaff remains approach each other, resulting in few hulled wheat grains and few freethreshing wheat rachis remains. Few of the free-threshing wheat grains were very compact. However, it is not clear if the free-threshing wheat is of the tetraploid (T. turgidum ssp. durum) or hexaploid (T. aestivum ssp. aestivum) type as differentiation of both wheat varieties is only possible by rachis remains. Barley finds are low in number compared to the wheat remnants. Still the number of barley grains is close to the number of hulled wheat grains. Rachis of barley were very seldom found. Legumes are represented mainly by lentil, with finds of faba bean (Vicia faba) and unspecified legumes (Fabaceae sativae). Grape pips and olive stones, linseed (Linum usitatissimum), and fig nutlets (Ficus carica) complement the assemblage of crop material. The finds of wild species are less numerous than those of cultigens. Most of the finds belong to the sweet grass (Poaceae) and legume family (Fabaceae) represented by darnel grass, canary/foxtail grass (Phalaris/Alopecurus sp.), trefoil and scorpion's tail (Scorpiurus sp.).

\section{Integration of the archaeobotanical data sets from the Hellenistic southern Levant}

The sites of Group 1 and 2 (Table 2) provide a good database to get an overview of the crops consumed in Hellenistic Palestine (Fig. 4). The data from sites of Group 3 and 4 confirm and extend the data of the first two groups. Cereals are the dominant crop species followed by legumes and fruit species. Grains of free-threshing wheat are numerous in almost every site of Group 1 and 2 (and at Tall Zirā'a of Group 3) whereas rachis finds of this crop only come from Tell Iztabba ( $\mathrm{N}=4$; Table 2). Residues of hulled wheat are mainly found as chaff and grains at Tell Izțabba with a dominance of chaff remains. At Tel Kedesh the amount of hulled wheat (only grains) is smaller. Apart from that, there are no other sites of Group 1 and 2 with finds of hulled wheat except for two grains found at Tell Mazar II. At Tell el-Hesi hulled wheat grains were found and documented as presence-only data but no chaff remains (Table 2). Barley is present in almost all of the sites of the Groups 1,2, and 3 with a clear dominance at Pella. Exceptional is the high abundance of non-identifiable cereal remains found at Tell Izțabba, Tel Kedesh and Tall al-'Umayri, which is most probably the result of the poor preservation status of plant remains. Possible oat glumes were only retrieved at Tel Kedesh (Table 2).

The variety of legumes found is quite substantial. Lentil and bitter vetch were found at almost all the sites in Group 1 and 2. Only the number of finds per species varies between the different sites, with lentil being the most numerous legume taxon at Tell Iztabba and bitter vetch the dominant legume species at Tel Kedesh and Hesban. Likewise, many finds of cultivated legumes could not be assigned to any certain taxon and were listed as Vicia/Lathyrus/Pisum sp. or Fabaceae sativae (Table 2). Single finds of chickpea were retrieved from Tall al- 'Umayri and Jiyeh/Porphyreon and two seeds of faba bean from Tell Iztabba. Noteworthy is the high number of legumes at Hesban where more than $50 \%$ of cultigens are assigned to cultivated legumes. At Tell el-Hesi we see a high variety of different pulses but without any hint as to the number of finds.

Oil and/or textile crops are represented by olive and flax. Flax only occurs at two sites where thousands of linseeds from Tell el-Mazar II contrast with the few linseed finds from Tell Izțabba (and Tell el-Hesi). Whole or fragmented olive stones were found at almost all sites in Group 1, Group 2 and Group 3, with a high proportion and ubiquity of olive finds at Jiyeh/Porphyreon together with many fig and grape finds. In general, the number of olive finds is similar to the number of grape pips and fig nutlets. Only in Tel Kedesh more than 500 fig nutlets have been found. Noteworthy are very few finds or even an absence of grape and fig at Pella, Hesban, and Tell el-Mazar II as well as at all the sites of Group 3 and 4 (except grape from Tell el-Hesi and fig from Giv'ati Lot/Jerusalem). Single finds of pomegranate, date and pear supplement the Hellenistic fruit assemblage. Moreover, the category of other cultigens includes the teeth of
Fig. 4 Percent proportions of the cultigens found at the Hellenistic sites of Group 1 and 2 from the southern Levant

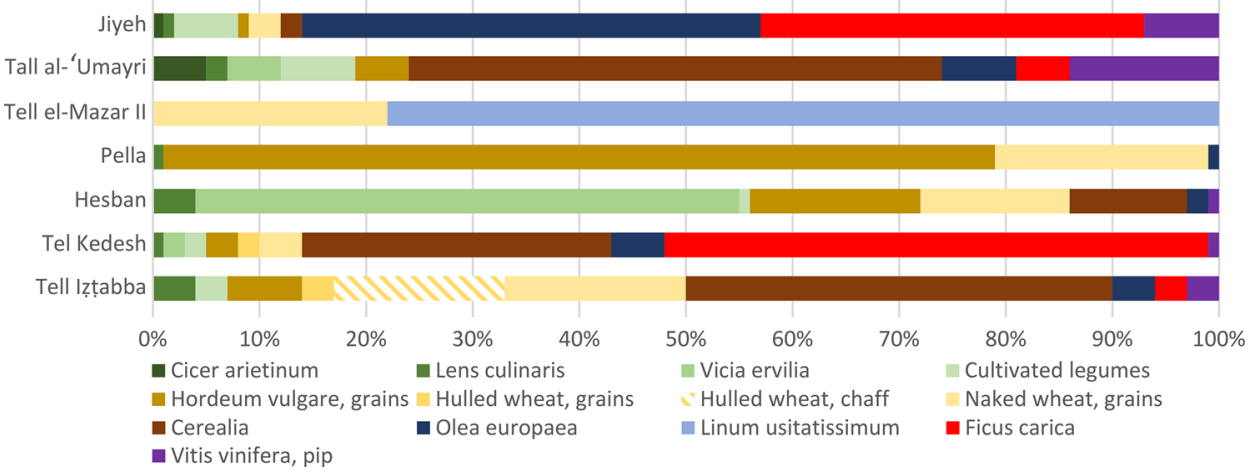


garlic from Cave V/49, one almond seed from Tell Izțabba and one pistachio nutlet found at Tel Kedesh.

\section{Discussion}

\section{The archaeobotanical assemblage of Tell Izțabba}

Due to its favourable natural conditions the Beth She'an Valley has been extensively farmed since Early Bronze Age times at the latest (Simchoni and Kislev 2006, 2012; Simchoni et al. 2007; Kislev et al. 2009). Archaeobotanical investigations on plant finds from the biblical Tel Beth She'an (Tell el-Husn) show that this area produced a huge variety of cultigens since the Bronze and Iron Age (third to first half of first millennium $\mathrm{BCE}$ ), including demanding crops.

The archaeobotanical finds of cultigens from Tell Iztabba are most probably relics of the crops processed and consumed at this site (Dennell 1972, 1974; Fuller et al. 2014). The archaeobotanical data is of typical southern Levantine character, indicating that the settlers of Tell Iztabba relied mainly on the cultivation and use of domestic crops as agrarian resources. Similar observations have been made for other colonial settings in the southern Levant (Crusader time Apollonia/Arsur, Orendi in press; Byzantine and Crusader time Khirbet Qana, Ramsay 2008, pp. 274-278).

Cereals account for the major part, followed by legumes and fruits. Cereal residues are mainly free-threshing wheat grains and chaff of hulled wheat. Barley comprised only a small proportion of the cereal assemblage. The wheat to barley ratio follows the trend of preferred wheat cultivation in the northwestern part of the southern Levant (except Pella; Fig. 4) where the water supply was more abundant and stable than in the southeast (Zohary 1962, pp. 20-22). At Tell Iztabba, the proportion of free-threshing to hulled wheat is almost similar. Rather the number of plant parts of both species differs significantly, as free-threshing wheat is found mainly as caryopses whereas the finds of hulled wheat are mainly represented by chaff remains (Table 1). The distribution of naked wheat grain and hulled wheat chaff might be the result of the different stages of crop processing inside and outside the settlement. In general, the processing of both cereals follows the same procedure. However, hulled wheat grains are stored as whole spikelets and before consumption the grains need to be de-husked by pounding and finally sieving to separate the grains from the chaff (Hillman 1984, 1985). The threshing of naked wheat was most probably done outside the densely built settlement, whereas the pounding and sorting of the hulled wheat grains was done near the food preparation areas inside the settlement, as Kreuz and Marinova (2017) formulated for Neolithic dwellings in Bulgaria. One can assume a similar scenario at Hellenistic Tell Iztabba where the composition of the domestic structures is suggestive of refuse areas where the final stages of cereal processing (fine sieving and/sorting of the cereals) took place (van der Veen 1992; Riehl 2004; Simchoni and Kislev 2012).

The finds of legumes are mainly either lentils or unidentifiable cultivated legume seeds. Only single finds of broad bean and some globular seeds of Vicia-/Lathyrus- or Pisumtype complement the protein-rich assemblage of pulses. Although the lentil only contains 2 seeds per pod and the yield of the seeds depends on the amount of rainfall (Riehl 2009), this crop is a common find on southern Levantine sites and outnumbers other legumes like pea, bitter vetch, chickpea or broad bean (Riehl and Kümmel 2005).

The fruit remains of olive, fig and grape are also part of the crop assemblage of many sites in the southern Levant (Riehl and Kümmel 2005). It is possible that fruit trees of all three species have been cultivated near the site or along the slopes of the Samaria or the Galilee mountains adjacent to the Beth She' an valley.

The composition of plant finds might be attributable to remnants of crops stored inside the silos along with typical field weeds like darnel grass. In addition, the carbonized plant remains may have entered the silos as waste and erosion after the silos fell out of use or the site was abandoned (Fuller et al. 2014). As both silos are part of a domestic dwelling, statements about possible contents distribution within the urban household economy cannot be made unless more such assemblages from the site are studied and published. Plant assemblages from silo contexts at different southern Levantine sites (Stewart 1978; Orendi et al. 2017) are also characterized by a high variety of cultivated and wild species, which accumulated inside the installations during and after their use.

What is striking about the archaeobotanical assemblage of Tell Iztabba is the high number of modern floral contaminants retrieved mainly from the bigger silo (L338). The most prominent of these come from the crown daisy and the small-flowered mallow. The modern seeds might have entered the sediments of ancient features through harvester ants (Messor sp.: Danin 2009a, b), field mice and/or snakes. The modern contaminants of the archaeobotanical assemblage from Tell Iztabba raise questions about the taphonomic processes on-site (like the duration of the filling of the storage contexts with sediments etc., e.g. Tel Kedesh: Borojevic 2011) and the age of the plant assemblage. Still, without radiocarbon dating of charred plant finds from selected contexts and layers, it is assumed that the carbonized (and mineralized) macro remains date to the Hellenistic period based on the archaeological context and finds recovered from these assemblages.

While the production of food is a fundamental property for a Seleucid-period founded town such as 
Nysa-Scythopolis, we must remember that its primary food production was made outside the perimeter of the inhabited town in cultivated fields within its hinterland. This hinterland formed an integral part of its jurisdiction area, being probably confined to its natural environment borders. Agricultural commodities such as grains, olives, grapevines, vegetables and fruits like those present in our assemblage were consumed by the town inhabitants and probably sold in local markets (Reger 2003). The mechanism of such an economic activity remains largely invisible to us and apart from getting familiar with the kinds of available agricultural products, we can only postulate probable models of consumption and investment (Davies 2001). The importance of the grapevine and olive for this economy cannot be undermined, but still our assemblages show the predominance of cereals in the site's botanical diet. Nevertheless, as much as our assemblage forms the largest well-secured Seleucid assemblage ever analysed in the southern Levant, it is too small to represent a reliable indication of the site's inhabitants' consumption preferences for the botanical component of their diet.

\section{The Hellenistic southern Levant data}

Despite the poor data pool of Hellenistic plant material from the region, it is possible to reconstruct a general trend in consumption of and trade in preferred agricultural crops (Table 2; Fig. 4). The agrarian resources of Hellenistic times do not differ from the preferred agrarian products of earlier periods (Riehl and Kümmel 2005; Orendi 2018). Free-threshing wheat and barley were the most important cereals in Hellenistic Palestine. The preference for either barley or free-threshing wheat depended on the location of the site and the environmental factors. The southeastern part of the southern Levant mainly cultivated barley due to low precipitation rates. This division of the southern Levant into barley- and wheat-dominated spheres is known since the Early Bronze Age (Riehl 2009; Orendi 2018). In accordance, the Transjordanian sites of Pella and Hesban, which are located in the semiarid belt of the southern Levant, show higher percent proportions of barley than freethreshing wheat. However, one should keep in mind that at Hesban barley grains only slightly outnumber finds of freethreshing wheat grains. Remnants of hulled wheat are only common at Tell Iztabba, Tel Kedesh, Tell el-Mazar II, and Tell el-Hesi. Hulled wheat finds are entirely lacking at Hesban, Pella, Tall al-'Umayri, Jiyeh, and all sites of Group 3 and 4 (except Tell el-Hesi) within which Pella and Hesban relied on barley (Fig. 4; Table 2). The same observation is made for the Bronze and Iron Age at many sites in the semi-arid regions of the southern Levant where hulled wheat is almost completely absent where barley is the dominant cereal. Here, there is a predominance of the cultivation of naked wheat as a complementary cereal to barley (e.g. Zahrat adh-Dhra, er-Ruqes,
Shilo, Manahat, Tell el-Far'ah (south), Hesban, and Tall al'Umayri-Riehl and Kümmel 2005).

Legumes were an important component of the Hellenistic diet and agriculture for various reasons. They are and were an integral part of peoples' diet, providing them with nonmeat proteins (seeds of lentil contain $25 \%$ protein) and other important nutrients like minerals, vitamins and amino acids. Moreover, legumes are natural fertilizers as they supply the soil of areas under cultivation with atmospheric nitrogen by fixing rhizobia to the root nodules (Zohary and Hopf 1973; Charles 1985; Zohary et al. 2012, p. 75; Kreuz and Marinova 2017). Lentil is commonly found at the Hellenistic sites but only at Tell Iztabba does the lentil outnumber the other pulses. At Tel Kedesh and Hesban the bitter vetch is of importance, whereas the chickpea was only found at Tell elHesi, Jiyeh, and Tall al-'Umayri. Based on the data and the spatial distribution it is not evident why one site preferably cultivated or consumed one specific leguminous species.

Since the Early Bronze Age, the central Jordan Valley, including the Beth She' an region, was a centre of flax cultivation and textile production (Orendi 2019), as mentioned in more than a few historical sources (Shamir et al. in press). The storage find of linseeds from Tell el-Mazar II is certainly evidence of the continued tradition of extensive flax cultivation and possibly linen production at this site from the Iron Age IIC up to Persian and Hellenistic times (Yassine and van der Steen 2012; Orendi 2019). Although the four carbonized linseeds from Tell Izțabba are not sufficient to attest to such large-scale cultivation of flax, they nevertheless constitute evidence for its cultivation/use as normally oil seeds often do not survive charring (Märkle and Rösch 2008).

Olive, grape and fig are common crops at the Hellenistic sites (Table 2, Fig. 4). At Jiyeh/Porphyreon the high abundance of fruit remains (olive, fig, grape) might point to extensive fruit growing activities in the central Levant. As yet, we cannot trace such specialization in fruit tree cultures for the rest of the Hellenistic southern Levant.

\section{Conclusions}

The archaeobotanical assemblage from Tell Izțabba represents the largest well-secured Seleucid assemblage ever analysed in the Hellenistic southern Levant. It shows a diet of typical southern Levantine character that was based on the cultivation and use of indigenous crops, whose traditions are rooted in much earlier periods. The fact that the Seleucid-period settlement foundation and destruction are historically documented and chronologically set within the last three quarters of the 2nd century BCE strengthens our suggestion of considerable local impact on colonized Seleucid settlements in the southern Levant. The site's inhabitants' botanical diet was in fact similar to 
that known from earlier periods in the region, similar to other aspects of material culture where the predominance of local trends and traditions is evident (Tal 2008, 2011; cf. also Coloru 2013 for the Seleucid empire in general).

It must be noted, however, that the data presented in this paper are a preliminary baseline for understanding the plant-based diet of a newly founded Hellenistic (Seleucid) settlement in the Near East. More studies are needed to flesh out the picture, but what is noticeable is that the Seleucid settlers did not introduce new agricultural practices and consumption habits. This result is remarkable because competing trends are evident. On the one hand, we can see evidence that products were imported from the Aegean, as attested by amphorae from Rhodes, Cos and Cnidos (Ebeling et al. 2020). On the other hand, we find the use of traditional local building techniques (with mud bricks) for the domestic structures on the site (Ebeling et al. 2020). These competing trends are proof of a complex adoption model of the new settlers. While some products were imported, most of the activities relating to the use of construction materials or agricultural production were rooted in local traditions. Of course, this does not come as a surprise since these activities were heavily reliant on the exploitation of the region's natural resources (indigenous inhabitants included) and adaptation to the local natural environment. Participating in this local knowledge suggests that the settlers did not live as isolated colonists but rather interacted with the local population and learnt from them how to efficiently exploit the natural resources of the Beth She'an Valley.

The botanical data from Tell Iztabba fits into the overall picture of the Hellenistic plant diet in the southern Levant. The investigation of the archaeobotanical data of Hellenistic Levantine sites has revealed that Hellenistic societies of this region relied on crops known from earlier periods and maintained local cultivation traditions e.g. increased naked wheat cultivation in the northwest of the southern Levant or flax cultivation in the central Jordan Valley. However, the analysis of these sites showed that there is still much more archaeobotanical work needed. Especially data lists with total numbers, not to mention sample-by-sample data, would enhance our understanding of agricultural developments in Hellenistic Palestine.

Supplementary Information The online version contains supplementary material available at https://doi.org/10.1007/s00334-020-00820 -z.Acknowledgements This study is supported by the German-Israeli Foundation (GIF) - Regular Program (Grant No. I-150-108.7-2017; Tell Iztabba [Nysa-Scythopolis]: High-resolution Hellenistic Settlement Archaeology and the Reassessment of the Formation of the Decapolis), headed by A. Lichtenberger, University of Münster and O. Tal, Tel Aviv University. We would like to thank Simone Riehl for permitting A. Orendi to use the reference collection of the Archaeobotany Laboratory of the University of Tübingen. We are indebted to the two anonymous reviewers and the associate editor whose comments improved this paper.

Funding Open Access funding enabled and organized by Projekt DEAL.. Open Access funding enabled and organized by Projekt DEAL.

Open Access This article is licensed under a Creative Commons Attribution 4.0 International License, which permits use, sharing, adaptation, distribution and reproduction in any medium or format, as long as you give appropriate credit to the original author(s) and the source, provide a link to the Creative Commons licence, and indicate if changes were made. The images or other third party material in this article are included in the article's Creative Commons licence, unless indicated otherwise in a credit line to the material. If material is not included in the article's Creative Commons licence and your intended use is not permitted by statutory regulation or exceeds the permitted use, you will need to obtain permission directly from the copyright holder. To view a copy of this licence, visit http://creativecommons.org/licenses/by/4.0/.

\section{References}

Badura M, Rzeźnicka E, Wicenciak U, Waliszewski T (2016) Plant remains from Jiyeh/Porphyreon, Lebanon (seasons 2009-2014): preliminary results of archaeobotanical analysis and implications for future research. Pol Archaeol Mediterr 25:487-510

Berlin AM, Ball T, Thompson R, Herbert SC (2003) Ptolemaic agriculture, "Syrian Wheat", and Triticum aestivum. J Archaeol Sci 30:115-121

Borojevic K (2011) Interpreting, dating, and reevaluating the botanical assemblage from Tell Kedesh: a case study of historical contamination. J Archaeol Sci 38:829-842

Cappers RTJ, Bekker RM, Jans JEA (2012) Digitale Zadenatlas van Nederland, 2nd edn. Barkhuis Publishing, Eelde

Charles MP (1985) An introduction to the legumes and oil plants of Mesopotamia. Bull Sumerian Agric 2:39-61

Colledge S, Conolly J, Shennan S (2004) Archaeobotanical evidence for the spread of farming in the eastern Mediterranean. Curr Anthropol 45(Suppl):S35-S57

Coloru O (2013) Seleukid Settlements: between ethnic Identity and Mobility. Electrum 20:37-56

Conolly J, Colledge S, Shennan S (2008) Founder effect, drift, and adaptive change in domestic crop use in early Neolithic Europe. J Archaeol Sci 35:2,797-2,804

Danin A (2009a) Chapter F: Relationship between plants and harvesting ants. Chrysanthemum coronarium and Calendula arvensis. Flora of Israel Online. https://flora.org.il/books/plant-stories-2/ chapter-h/useful_plants_h5/. Accessed 8 June 2020

Danin A (2009b) Chapter F: Relationship between plants and harvesting ants. Beta and Malva near ant nests. Flora of Israel Online. https://flora.org.il/books/plant-stories-2/chapter-h/useful_plant s_h6/. Accessed 8 June 2020

Davies JK (2001) Hellenistic economies in the post-Finley era. In: Archibald ZH, Davies JK, Gabrielsen V, Oliver GJ (eds) Hellenistic economies. Routledge, London, pp 11-62

Dennell RW (1972) The interpretation of plant remains: Bulgaria. In: Higgs ES (ed) Papers in economic prehistory. Cambridge University Press, Cambridge, pp 149-159

Dennell RW (1974) Botanical evidence for prehistoric crop processing activities. J Archaeol Sci 1:275-284 
Dennell RW (1992) The origins of European crop agriculture. In: Watson PJ, Cowan W (eds) The origins of crop agriculture. Smithsonian Institute Publications, Washington, pp 71-100

Ebeling B, Edrey M, Harpak T, Lichtenberger A, Tal O (2020) Field report on the 2019 German-Israeli Tell Istabbā Excavation Project (Beth She'an), Israel. Zeitschrift des Deutschen Palästina-Vereins $136 / 2$

Ebeling B, Edrey M, Harpak T, Lichtenberger A, Tal O (2021) Field report on the 2020 German-Israeli Tell Iștabbā Excavation Project (Beth She'an), Israel. Zeitschrift des Deutschen Palästina-Vereins $137 / 1$

Effenberger H (2018) The plant economy of the Northern European Bronze Age-more diversity through increased trade with southern regions. Veget Hist Archaeobot 27:65-74

Frumin SI, Tchekhanovets Y (2016) Plant imprints on pottery reveal fig tree in Hellenistic Jerusalem. Isr Explor J 66:188-201

Fuller DQ, Stevens C, McClatchie M (2014) Routine activities, tertiary refuse and labor organization: social inference from everyday archaeobotany. In: Madella M, Lancelotti C, Savard M (eds) Ancient plants and people: contemporary trends in archaeobotany. University of Arizona Press, Tucson, pp 174-217

Gilliland DR (1986) Paleoethnobotany and paleoenvironment. In: LaBianca ØS, Lacelle L (eds) Environmental foundations. Hesban 2. Andrews University Press, Berrien Springs, pp 123-142

Hillman G (1984) Traditional husbandry and processing of archaic cereals in recent times: the operations, products and equipment which might feature in Sumerian Texts. Part I: the Glume Wheats. Bull Sumerian Agric 1:114-151

Hillman G (1985) Traditional husbandry and processing of archaic cereals in recent times: the operations, products and equipment which might feature in Sumerian Texts. Part II: the Free-Threshing Cereals. Bull Sumerian Agric 2:1-31

Hölscher T (ed) (2006) Klassische Archäologie: Grundwissen. Wissenschaftliche Buchgesellschaft, Darmstadt

Jacomet S (2006) Identification of cereal remains from archaeological sites, 2nd edn. Archaeobotany Lab, IPAS, Basel University, Basel

Kislev ME, Simchoni O, Melamed Y, Maroz L (2009) Chapter 17A: Food and industrial crops. In: Panitz-Cohen N, Mazar A (eds) Excavations at Tel Beth-Shean 1989-1996, Vol 3: The 13th-11th century BCE strata in areas $\mathrm{N}$ and $\mathrm{S}$, vol 3. The Israel Exploration Society, Jerusalem, pp 764-771

Kreuz A, Marinova E (2017) Archaeobotanical evidence of crop growing and diet within the areas of the Karanovo and the Linear Pottery Cultures: a quantitative and qualitative approach. Veget Hist Archaeobot 26:639-657

Lichtenberger A, Meyer C, Tal O (2020) Magnetic prospecting at NysaScythopolis (Tell Izțabba, Beth She'an, Israel): deciphering urban planning at a newly founded Hellenistic town of the Decapolis, vol 38. The Bulletin of the Anglo-Israel Archaeological Society, Strata, pp 45-70

Liphschitz N, Waisel Y (1989) Botanical remains. In: Herzog Z, Negbi O, Rapp G (eds) Excavations at Tel Michal, Israel. University of Minnesota Press, Minneapolis, pp 219-222

Liphschitz N, Waisel Y (1992) Macrobotanical remains. In: de Groot A, Ariel DT (eds) Excavations at the City of David 1978-1985, Vol 3: Stratigraphical, environmental, and other reports. Qedem 33. Hebrew University of Jerusalem, Jerusalem, pp 105-121

Märkle T, Rösch M (2008) Experiments on the effects of carbonization on some cultivated plant seeds. Veget Hist Archaeobot 17(Suppl 1):S257-S263

McCorriston J, Weisberg S (2002) Spatial and temporal variation in Mesopotamian agricultural practices in the Khabur Basin, Syrian Jazira. J Archaeol Sci 29:485-498

Melamed Y (2002) Chalcolithic and Hellenistic plant remains from Cave V/49. Atiqot 41:101-108
Neef R, Cappers RTJ, Bekker RM (2012) Digital atlas of economic plants in archaeology. Barkhuis Publishing \& Groningen University Library, Groningen

Nesbitt M (2006) Identification guide for near eastern grass seeds. Taylor \& Francis, London

Neumann F, Schölzel C, Litt T, Hense A, Stein M (2007) Holocene vegetation and climate history of the northern Golan heights (Near East). Veget Hist Archaeobot 16:329-346

Neumann FH, Kagan EJ, Leroy SAG, Baruch U (2010) Vegetation history and climate fluctuations on a transect along the Dead Sea west shore and their impact on past societies over the last 3500 years. J Arid Environ 74:756-764

Olsvig-Whitaker L (2017) Chapter 3.7: Archaeobotany. In: Vieweger D, Häser J (eds) Tall Zirā'a the Gadara Region project (20012011). Gütersloher Verlagshaus, Gütersloh, pp 206-211

Orendi A (2018) Entwicklung und Bedeutung agrarischer Ressourcen in der Südlevante der Bronze- und Eisenzeit. Dissertation. Eberhard Karls Universität Tübingen, Tübingen

Orendi A (2019) Flax cultivation in the southern Levant and its development in the Bronze and Iron Age. Quat Int 545:63-72

Orendi A (in press) Archaeobotanical remains. In: Tal O (ed) Apollonia-Arsuf: final report of the excavations, Vol 3: Crusader Arsur. Penn State University Press, Pennsylvania

Orendi A, Smejda L, McKinny C, Cassuto D, Sharp C, Shai I (2017) The agricultural landscape of Tel Burna: Ecology and economy of a Bronze Age/Iron Age settlement in the southern Levant. J Landscape Ecol 10:167-188

Orni E, Efrat E (1966) Geographie Israels. Israel University Press, Jerusalem

Perry Gal L (2019) Faunal remains. In: Stern I (ed) Excavations at Maresha Subterranean Complex 169. Final Report Seasons 20002016. Annuals of the Nelson Glueck School of Biblical Archaeology 11. Nelson Glueck School of Biblical Archaeology, Jerusalem, pp 197-212

Pines M, Dor A, Bar-Yosef Mayer DE, Paz S, Tal O, Greenberg R (2020) Heads or snails? A rustic feast at Hellenistic Philoteria (Tel Bet Yerah, Israel), circa 150 BCE. J East Mediterr Archaeol Heritage Stud 8:79-93. https://muse.jhu.edu/article/750988

Ramsay J (2008) Seeds of imperialism: a core/periphery study in the eastern Roman Empire. Dissertation. Simon Fraser University, Burnaby

Ramsay J, Mueller N (2016) Telling seeds: archaeobotanical investigations at Tall al-'Umayri, Jordan. In: McGeough KM (ed) The archaeology of agro-pastoralist economies in Jordan. The Annual of the American Schools of Oriental Research 69. American Schools of Oriental Research, Boston, pp 1-25

Reger G (2003) The economy. In: Erskine A (ed) A companion to the hellenistic world. Wiley-Blackwell, Oxford, Malden, pp 331-353

Riehl S (2004) Archaeobotany at the Early Bronze Age settlement of Hirbetez-Zeraqōn. A preliminary report. Zeitschrift des Deutschen Palästina-Vereins 120:101-122

Riehl S (2009) Archaeobotanical evidence for the interrelationship of agricultural decision-making and climate change in the ancient Near East. Quat Int 197:93-114

Riehl S, Kümmel C (2005) Archaeobotanical database of Eastern Mediterranean and Near Eastern sites. http://www.cuminum.de/ archaeobotany/. Accessed 9 July 2020

Shamir O, Lichtenberger A, Tal O (in press) The Relationship between Textile Remains on a Hoard of Alexander II Zebinas Coins (129/28-126/25 BCE) and Loom weights from Tell Izțabba (Beth She'an, Nysa-Scythopolis), Israel. In: Berghe V, Grömer K, Ulanowska A (eds) Ancient Textile Production from an Interdisciplinary Approach: Humanities and Natural Sciences Interwoven for Our Understanding of Textiles. Interdisciplinary Contributions to Archaeology. Springer, Berlin 
Simchoni O, Kislev ME (2006) Charred by-products of olive-oil production in the Iron Age. In: Mazar A (ed) Excavations at Tel BethShean 1989-1996, Vol 1: From the Late Bronze Age IIB to the medieval period. The Israel Exploration Society, Jerusalem, pp 679-686

Simchoni O, Kislev ME (2012) Chapter 12A: Food and fodder in Early Bronze Age strata in Area M. In: Mazar A (ed) Excavations at Tel Beth-Shean 1989-1996, Vol 4: The 4th and 3rd Millennia BCE. The Israel Exploration Society, Jerusalem, pp 422-429

Simchoni O, Kislev ME, Melamed Y (2007) Chapter 15A: Beth-Shean as a trade center for crops in the Bronze Age: botanical and entomological evidence. In: Mazar A, Mullins RA (eds) Excavations at Tel Beth-Shean 1989-1996, Vol 2: The Middle and Late Bronze Age strata in Area R. The Israel Exploration Society, Jerusalem, pp 702-715

Singer A (2007) The soils of Israel. Springer, Berlin, Heidelberg

Stewart RB (1978) Archeobotanic studies at Tell el-Hesi. Econ Bot 32:379-386

Stika H-P, Heiss AG (2013) Bronzezeitliche Landwirtschaft in Europa - Der Versuch einer Gesamtdarstellung des Forschungsstandes. In: Willroth K-H (ed) Siedlungen der älteren Bronzezeit. Beiträge zur Siedlungsarchäologie und Paläoökologie des zweiten vorchristlichen Jahrtausends in Südskandinavien, Norddeutschland und den Niederlanden. Studien zur nordeuropäischen Bronzezeit 1. Beiträge zur, Wachholtz, Neumünster, pp 189-222

Tal O (2008) Cult in transition from Achaemenid to Greek Rule: the contribution of Achaemenid-Ptolemaic temples of palestine. Transeuphratène 36:165-183

Tal O (2011) 'Hellenistic Foundations' in Palestine. In: Grabbe LL, Lipschits $\mathrm{O}$ (eds) Judah between East and West: the transition from Persian to Greek Rule (ca. 400-200 BCE). Library of second temple studies 75. Bloomsbury, London, New York, pp 242-254
Tal O (2017) Hellenistic philoteria in its architectural and historical contexts. In: Greenberg R, Tal O, Da'adli T. Bet Yerah (eds) Volume III: Hellenistic Philoteria and Islamic al-Șinnabra. IAA Reports 61. Israel Antiquities Authority, Jerusalem, pp. 97-121

Thiel W (2007) Untersuchungen zum hellenistischen Siedlungswesen in Palästina und Transjordanien. Dr. Hut, München

Van der Veen M (1992) Crop husbandry regimes: an archaeobotanical study of farming in northern England 1000 BC-AD 500. Sheffield Archaeological Monographs 3. J. R. Collis Publications, Sheffield

Willcox G (1992) Archaeobotanical investigations at Pella (1983). In: McNicoll AW, Edwards PC, Hanbury-Tenison J, Hennessy JB, Potts TF, Smith RH, Walmsley A, Watson P (eds) Pella in Jordan 2: The second interim report of the joint University of Sydney and College of Wooster excavations at Pella 1982-1985. Mediterranean Archaeology Supplement 2. Australian National Gallery, Canberra, pp 253-256

Yassine K, van der Steen E (2012) Tell el-Mazar II: Excavations on the Mound 1977-1981: Field I. BAR International Series 2430. Archaeopress, Oxford

Zohary D, Hopf M (1973) Domestication of pulses in the Old World. Science 182:887-894

Zohary D, Hopf M, Weiss E (2012) Domestication of plants in the old world: the origin and spread of domesticated plants in Southwest Asia, Europe, and the Mediterranean Basin. Oxford University Press, Oxford

Zohary M (1962) Plant life of Palestine, Israel and Jordan. Ronald Press Company, New York

Publisher's Note Springer Nature remains neutral with regard to jurisdictional claims in published maps and institutional affiliations. 